\title{
PERANCANGAN DAN IMPLEMENTASI E LEARNING BERBASIS WEB PADA UNIVERSITAS DHYANA PURA DENGAN METODE RANDOM MATRIX
}

\author{
Ni Putu Dian Kartika Sari ${ }^{1)}$ Wayan Supriana ${ }^{2)}$ Made Agung Raharja ${ }^{3)}$ \\ Program Studi Teknik Informatika ${ }^{1)}$ ) 3) \\ Fakultas IlmuKesehatanSainsdanTeknologi, Universitas Dhayana Pura, Badung, Bali ${ }^{1)^{2}}$ ) 3) \\ kartikadyanx@gmail.com ${ }^{1)}$ supriana@undhirabali.ac.id ${ }^{2)}$ agungraharja@undhirabali.ac.id ${ }^{3)}$
}

\begin{abstract}
Dhyana Pura University is a university that has a website as a means to provide information to students and the public, but on the web that is owned by the University Dhyana Pura does not have E-learning facilities. One way to make teaching and learning process more effective and efficient is to design and implement e-learning information system so that the teaching and learning process can not only be done while in the classroom, but not limited by space and time.

E-Learning is a type of teaching learning that allows the delivery of teaching materials to students by using the media Internet, Intranet or other computer network media.

The results of this study is a web-based information system that contains some facilities such as quiz that allows students to implement quiz online. This research uses Random Matrix method, where the quiz which is done by the student will be randomized. Web-based online learning system is built to support the process of lectures by using an electronic system, so as to be able to support a learning process and can provide a new venue about teaching learning process especially for students at Dhyana Pura University.
\end{abstract}

Keyword :Dhyana Pura University, Information System, Website, Internet, Random Matrix.

\begin{abstract}
ABSTRAK
UniversitasDhyana Pura adalah universitas yang telah memiliki website sebagai sarana untuk memberi informasi kepada mahasiswa dan publik, namunpada web yang telah dimiliki oleh Universitas Dhyana Pura belum memiliki fasilitas E-learning. Salah satu cara untuk membuat proses belajar mengajar menjadi lebih efektif dan efisien adalah dengan merancang dan mengimplementasikan sistem informasi e-learning sehingga proses belajar mengajar tidak hanya bisa dilaksanakan saat di kelas saja, tapi tidak terbatas oleh ruang dan waktu.

E-Learning merupakan suatu jenis belajar mengajar yang memungkinkan tersampaikannya bahan ajar ke siswa dengan menggunakan media Internet, Intranet atau media jaringan komputer lain.

Hasil penelitian ini adalah sistem informasi berbasis web yang berisi beberapa fasilitas seperti quiz yang memungkinkan mahasiswa melaksanakan quiz secara online. Penelitian ini menggunakan metode Random Matrix, dimana quiz yang kerjakan oleh mahasiswa akan diacak secara random. Sistem pembelajaran online berbasis web ini dibangun untuk menunjang proses perkuliahan dengan menggunakan suatu sistem elektronik, sehingga mampu untuk mendukung suatu proses pembelajaran dandapat memberikan vasilitasbaru mengenai proses belajar mengajar khususnya bagi mahasiswa pada Universitas Dhyana Pura.
\end{abstract}


Kata kunci :UniversitasDhyana Pura, Sisteminformasi, Website, Internet, Random Matrix.

\section{PENDAHULUAN}

Saat ini konsep e-learning sudah banyak diterima oleh masyarakat dunia, terbukti dengan maraknya implementasi e-learning di lembaga pendidikan maupun industri. Pada saat ini banyak metode belajar mengajar yang di gunakan salah satunya elektronic learning atau lebih sering kita kenal dengan istilah elearning. E-Learning adalah pembelajaran disusun dengan tujuan menggunakan suatu sistem elektronik atau juga komputer, sehingga mampu untuk mendukung suatu proses pembelajaran (Michael, 2013:27).

Selama ini beberapa universitas yang proses pembelajarannya masih bersifat konvensional, dengan kata lain bahwa proses belajar mengajar antara mahasiswa dengan dosen hanya dapat dilakukan dengan syarat terjadinya pertemuan antara mahasiswa dengan dosen di dalam kelas. Jika pertemuan antara mahasiswa dengan dosen tidak terjadi maka secara otomatis proses pembelajaran pun akanterhambat. Selainitu proses transfer ilmu hamper sepenuhnya dilakukan didalam kelas yang menyebabkan proses transfer ilmu bisa terhambat jika pertemuan tidak terjadi. Kelebihan e-learning yaitu memberikan fasilitas melalui internet secara reguler atau kapansaja kegiatan berkomunikasi itu dilakukan tanpa dibatasi oleh jarak, tempat dan waktu sehingga proses pembelajaran menjadi relatif lebih efisien.

\section{TINJAUAN PUSTAKA}

E-learning merupakan suatu pembelajaran dengan menggunakan internet dansegala perlengkapannya sebagai media. "Electronic Learning" disampaikan dengan menggunakan media elektronik yang terhubung dengan internet (world wide web/www yang menghubungkan semua unit komputer di seluruh dunia yang terkoneksi dengan internet) dan intranet (jaringan yang bisa menghubungkan semua unit komputer dalam sebuah lingkungan tertentu/terbatas).

\section{Fitur E-learning}

E-learning memiliki fitur-fitur sebagai berikut (Clark \& Mayer, 2008, p. 10):

Konten yang relevan dengan tujuan belajar.
Pada website Universitas Dhyana Pura sendiri belum memiliki fasilitase-learning, dengan alasan tersebut penulis ingin membuat suatu sarana untuk mengelola dan memudahkan dalam penyebaran artikel, makalah, maupun ilmu pengetahuan lain khususnya di bidang TI yang ditujukan untuk memberikan pendidikan gratis bagi masyarakat umum. Maka penulis menganggap perlu dibuat suatu aplikasi $e$ learning berbasis web yang dapat diakses kapan saja dan dimana saja sehingga mendukung proses pendidikan. Dalam pembuatan sistem penulis menggunakan metode random matrix, metode ini merupakan pengacakan yang terintegrasi dengan klasifikasi dan jumlah soal tersusun dalam pola matrix yang dipresentasikan dalam format array penulis menyebutnya Random Matrix.Setiap ujian yang dikerjakan setiap siswa memiliki random matrix sendiri - sendiri, random matrix disimpan di dalam database dalam bentuk XML sehingga memungkinkan soal ujian yang sudah dikerjakan dapat dibuka kembali persis ketika siswa pertama kali mengerjakannya, hal ini berguna untuk audit soal.

Berdasarkan latarbelakangdiataspenulis tertarik untuk melakukan penelitian dengan judul "Perancangan dan Implementasi E-learning Berbasis Web Pada Universitas Dhyana Pura Dengan Metode Random Matrix.

Menggunakan metode instruksional seperti contoh dan praktek untuk membantu belajar.

Menggunakan elemen media seperti kalimat dan gambar untuk mendistribusikan konten dan metode belajar.

\section{Keuntungan Menggunakan E-learning}

Ada beberapa keuntungan yang bisa diambil dari penggunaan e-learning, yaitu :

Fleksibelitas

Siswa tidak perlu mengadakan perjalanan menuju tempat pelajaran disampaikan, $e$ learning bisa diakses dari mana saja yang memiliki akses ke Internet. 
Pembelajaran yang Independen

E-learning memberikan kesempatan bagi pebelajar untuk memegang kendali atas kesuksesan belajar masing-masing dan objek multimedia lainnya (seperti MIDI, Shockwave, Quicktime Movie, 3D World).Karena web begitu popular, banyak orang kemudian salah mengidentikkannya dengan internet (Simarmata, 2006).

\section{Definisi Website}

Website adalah sebuah sistem dengan informasi yang disajikan dalam bentukteks, gambar, suara, dan lain - lain yang tersimpan dalam sebuah server web internet yang disajikan dalam bentuk hiperteks. Informasi web dalam bentuk teks umumnya ditulis dengan format HTML (Hypertext Markup Languag). Informasi lainnya dapat disajikan dalam bentuk grafis (dalam format GIF, JPG, PNG), suara (dalam format AU, WAV), dan objek multimedia lainnya (seperti MIDI, Shockwave, Quicktime Movie, 3D World). Karena web begitu popular, banyak orang kemudian salah mengidentikkannya dengan internet ( Simarmata, 2006 ).

\section{Jenis - Jenis Website}

Secara umum, situs web digolongkan menjadi 3 jenis yaitu: website statis, website dinamis, website interaktif.

Website Statis

Website Statis adalah web yang mem-punyai halaman tidak berubah. Artinya adalah untuk melakukan perubahan pada suatu halaman dilakukan secara manual dengan mengedit code yang menjadi struktur dari situs itu.

Website Dinamis

Website Dinamis merupakan website yang secara struktur diperuntukan untuk update sesering mungkin. Biasanya selain utama yang bisa diakses oleh user pada umumnya, juga disediakan halaman back-end untuk mengedit kontent dari website. Contoh umum mengenai website dinamis adalah web berita atau web portal yang didalamnya terdapat fasilitas berita, polling dan sebagainya.
Website Interaktif

Website Interaktif adalah web yang saat ini memang sedang booming. Salah satu contoh website interaktif adalah blog dan forum. Di website ini user bisa berinteraksi dan beradu argument me-ngenai apa yang menjadi pemikiran mereka. Biasanya website seperti me-miliki moderator untuk mengatur supaya topik yang diperbincangkan tidak me-lenceng dari alur pembicaraan.

\section{Unsur - Unsur Penunjang Dalam Website Atau Situs}

Untuk membangun sebuah website yang lebih advance, kita juga diharuskan untuk menyediakan unsur penunjang lainnya. Diantara unsur-unsur website itu adalah sebagai berikut:

Nama domain

Domain Name atau URL adalah alamat unik di dunia internet yang digunakan untuk mengenali sebuah situs, atau dengan kata lain nama domain adalah alamat yang digunakan untuk menemukan sebuah website di internet.

Web Hosting

Web Hosting adalah ruangan yang ter-dapat dalam harddisk tempat menyimpan berbagai data, file-file, gambar dan lainnya yang akan di-tampilkan di website. Besarnya data yang bisa dimasukkan tergantung dari besarnya web hosting yang disewa atau dimiliki, semakin besar web hosting semakin besar pula data yang dapat dimasukkan dan ditampilkan dalam website.

\section{Bahasa Pemerograman}

Bahasa program adalah bahasa yang digunakan untuk menerjemahkan setiap perintah dalam website yang pada saat diakses. Jenis bahasa program sangat menentukan statis, dinamis atau interaktifnya sebuah website. Semakin banyak ragam bahasa program yang digunakan maka akan terlihat website semakin dinamis, dan interaktif serta terlihat bagus. Beragam bahasa program saat ini telah hadir untuk mendukung kualitas website.

\section{Desain Website}

Unsur website yang penting dan utama adalah desain. Desain website me-nentukan kualitas dan keindahan sebuah website. Desain sangat 
berpengaruh kepada penilaian pengunjung akan bagus tidaknya sebuah website. Serta mempengaruhi dengan kenyamanan konsumen atau pembaca.
Metode random matrix adalah pengacakan yang terintegrasi dengan klasifikasi dan jumlah soal tersusun dalam pola matrix yang dipresentasikan dalam format array penulis.

\section{Random Matrix}

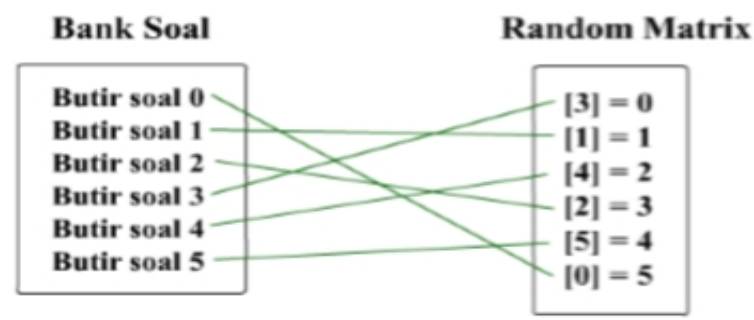

\section{Gambar 1.Pemetaan Random Matrix}

\section{Metode Pengembangan Perangkat Lunak}

Dalam membuat e-learning ini penulis menggunakan metode waterfall, metode ini merupakan salah satu metode yang sering digunakan oleh penganalisa sistem pada umumnya. Inti dari metode waterfall adalah pengerjaan dari suatu sistem dilakukan secara berurutan atau secara linear.Jadi jika langkah ke-1 belum dikerjakan, maka langkah ke-2 tidak dapat dikerjakan, jadi harus mengikuti tahapan demi tahapan untuk bisa lanjut pada langkah selanjutnya. Beberapa tahapan metode waterfall akan dijelaskan sesuai yang dilakukan dalam pembuatan aplikasi padaTugas akhir ini :

System information engineering and modeling :Sistem informasi teknik dan pemodelan ini, pada sistem ini penulis mencari kebutuhan dari keseluruhan sistem yang akan diaplikasikan kedalam software.

Requirements analysis :Analisiskebutuhan, setelah mencari kebutuhan yang ada di sistem selanjutnya kebutuhan ini akan diintensifkan dan difokuskan pada pembuatan software dengan selanjutnya merancang interface.

Design :Setelah dirancang interface maka yang diperlukanya itu atribut yang akan digunakan berupa struktur, arsitektur, algoritma, dan karakteristik yang dipakai untuk menjalankan sistem ini

Coding :Pada tahapan ini design yang telah dirancang akan diubah kedalam Bahasa pemrograman atau menerjemahkan data yang dirancang kedalam Bahasa pemrograman agar nantinya dapat dimengerti oleh mesin computer.

Testing :Ujicoba terhadap program yang dibuat, apabila error maka harus kembali ketahapan coding untuk mencari kesalahan yang ada.

Maintenance :Pemeliharaan, pada tahapan ini perubahan dan penambahan program dilakukan sesuai dengan permintaan.

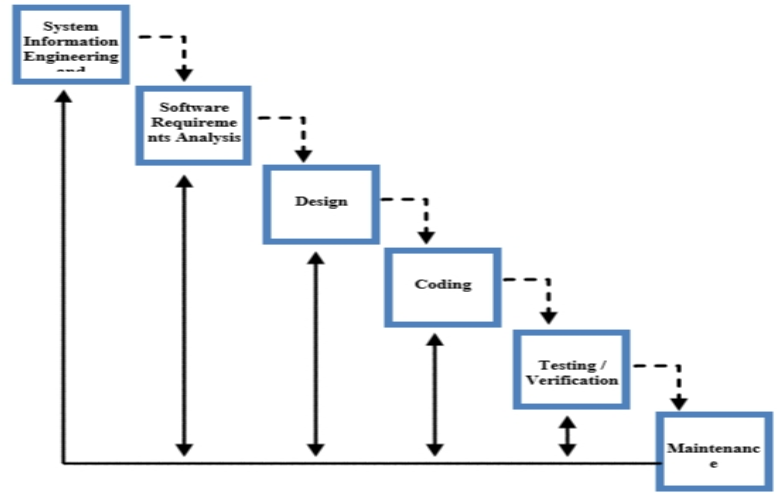

Gambar 2. Langkah - LangkahPenelitianMetode Waterfall 


\section{METODELOGI PENELITIAN \\ Metode Pengumpulan Data \\ Studi Literatur}

Pada tahap ini, dilakukan kegiatan pengumpulan data-data pendukung dan literatur untuk membangun aplikasi serta karakteristik lingkungan pengembangan sistem. Sumber-sumber yang didapatkan berupa jurnal, buku, dan beberapa informasi yang relevan dengan penelitian untuk menunjang fitur $e$ learning.

\section{Observasi}

Kegiatan pengumpulan data yaitu dengan meninjau langsung tempat penelitian yakni Universitas Dhyana Pura Bali dan mengumpulkan informasi mengenai media pembelajaran apa saja yang telah digunakan di Universitas Dhyana Pura.

\section{Analisis Dan PerancanganSistem}

Analisis sistem bertujuan untuk mengidentifikasi permasalahan yang terdapat pada sistem serta menetukan kebutuhan dari sistem yang akan dibangun. Analisis tersebut meliputi analisis masalah, analisis sistem yang sedang berjalan, analisis arsitektur sistem, analisis kebutuhan fungsional dan kebutuhan non fungsional. Analisis sistem merupakan penguraian dari suatu sistem yang utuh ke dalam bagian-bagian komponennya dengan maksud untuk mengidentifikasi dan mengevaluasi permasalahan yang terjadi dan kebutuhan yang diharapkan sehingga dapat diusulkan solusi. Dari hasil analisis tersebut maka dapat dibuat sistem informasi e-learning untuk pembelajaran secara online sehingga memudahkan proses belajar mengajar.

Tabel1.AnalisisKebutuhanFungsional

\begin{tabular}{|c|c|c|}
\hline $\mathbf{N}$ & Deskripsi Kebutuhan & Keterangan \\
\hline 1 & $\begin{array}{l}\text { Memberikan informasi kepada } \\
\text { mahasiswa }\end{array}$ & $\begin{array}{l}\text { Memberikan informasi kepada berupa materi } \\
\text { pelajaran dan pengumuman seputar perkuliahan, } \\
\text { tugas dan kuis melalui forum diskusi. }\end{array}$ \\
\hline 2 & $\begin{array}{l}\text { Informasi berupa teks yang di } \\
\text { informmasikan secara jelas dan } \\
\text { efisien. }\end{array}$ & $\begin{array}{l}\text { Informasi yang disampaikan kepada mahasiswa } \\
\text { disampaikan secara jelas dan tidak terbatas ruang } \\
\text { dan waktu. }\end{array}$ \\
\hline 3 & Mengolah data $u s e r$ & $\begin{array}{l}\text { Menginput dan merubah data - data dosen } \\
\text { pengajar, mahasiswa dan admin. }\end{array}$ \\
\hline 4 & Mengolah proses E-learning & $\begin{array}{l}\text { Menginput dan merubah materi, tugas, kuis dan } \\
\text { ujian online. }\end{array}$ \\
\hline 5 & Mengolah data nilai & $\begin{array}{l}\text { Menginput dan merubah nilai kuis dan ujian } \\
\text { mahasiswa. }\end{array}$ \\
\hline
\end{tabular}

\section{Analisis Kebutuhan Non Fungsional}

Adapun kebutuhan non fungsional untuk menjalankan aplikasi ini meliputi kebutuhan perangkat lunak dan kebutuhan perangkat keras.Analisis kebutuhan non fungsional bertujuan agar aplikasi yang dibangun dapat digunakan sesuai dengan kebutuhan pengguna aplikasi dalam mencari informasi yang dibutuhkan.

Kebutuhan Perangkat Lunak

Dalam analisis perangkat lunak ini dibagi menjadi dua yaitu analisis perangkat lunak untuk pengembang dan analisis perangkat lunak untuk pengunjung. Adapun perangkat lunak yang dibutuhkan untuk membangun sistem informasi e-learning antara lain:
a. Sistem Operasi Windows 7 Profesional
b. Xampp
c. Notepad ++
d. Web server Apache 1.3 atauversi yang terbaru.
e. PHP 5 atauversi yang terbaru.
f. DBMS MySQL 
Kebutuhan Perangkat Keras,

Sistem memerlukan perangkat keras dalam proses pembuatannya. Adapun perangkat keras tersebut minimal memilki spesifikasi sebagai berikut:

a. Processor Pentium III, dengan kecepatan 667 Mhz.

b. $R A M$ dengan kapasitas minimal 256 $\mathrm{MB}$.

c. Harddisk minimal $50 \mathrm{MB}$. d. Monitor VGA atau SVGA dengan resolusi minimal $1024 \times 768$

\section{Perancangan Sistem}

Proses perancangan mengubah kebutuhan kebutuhan menjadi bentuk karakteristik yang dimengerti perangkat lunak sebelum memulai penulisan program. Perancangan yang akan dilakukan pada pengembangan system yang diusulkan.

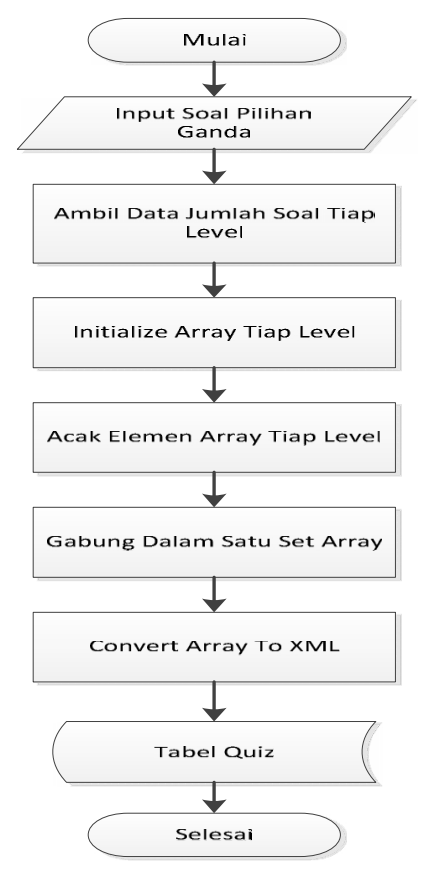

Gambar 3. Flowchart Random matrix

Pada gambar 3 ini, menggambarkan urutan proses metode random matrix yang dilakukan oleh sistem, di mulai dari input soal pilihan ganda yang kemudian dilanjutkan dengan proses pengambilan data jumlah soaltiap level, initialize data jumlah soal tiap array, kemudian acak elemen array tiap level, gabung dalam satu set array, convert array to xml kemudian data akan disimpan di database table quiz. 


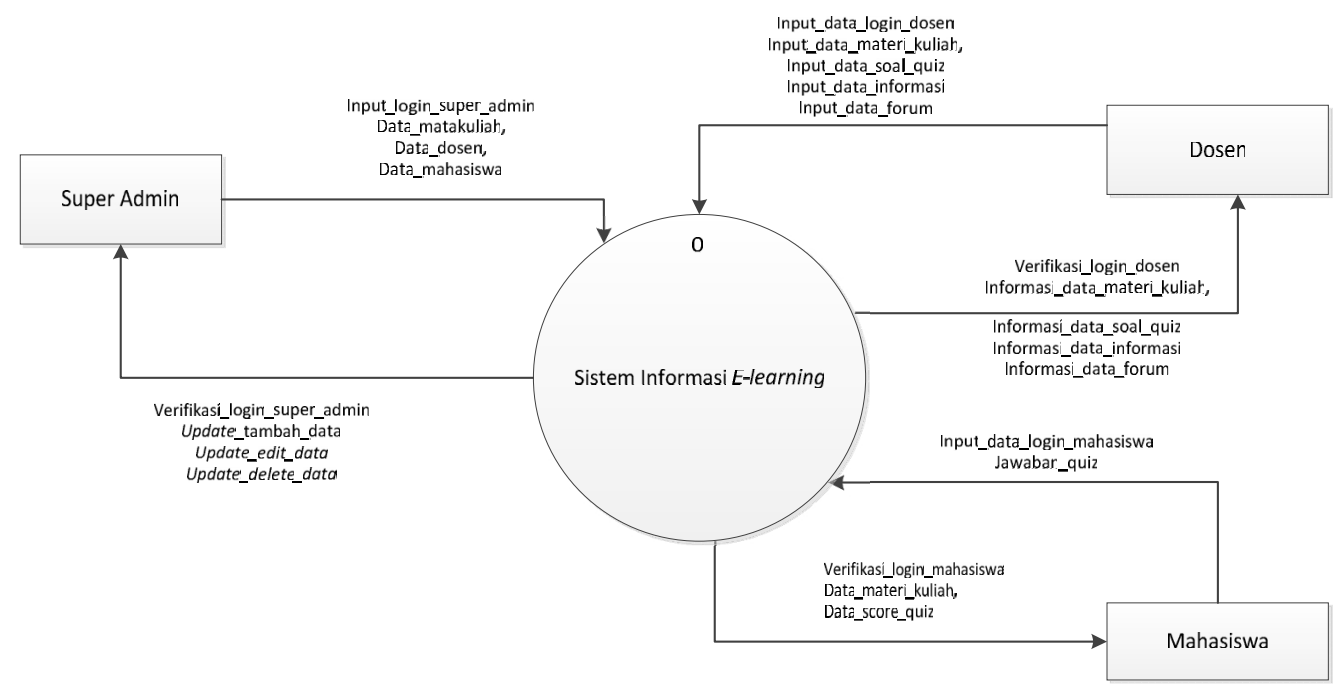

Gambar 4. Context DiagramE-Learning.

Pada gambar 4 menggambarkan diagram context perancangan sistem informasi e-learning pada Universitas Dhyana Pura memiliki 3 entitas, yaitu super admin, dosen dan mahasiswa. Super admin dapat mengelola dan melihat semua data. Dosen dapat mengeelola materi, quiz, dan forum. Sedangkan mahasiswa dapat mengakses informasi, melihat materi, mengerjakan quiz serta bergabung di forum.

\section{HASIL DAN PEMBAHASAN} Implementasi Antar Muka

Pada bab ini penyusun akan membahas mengenai implementasi sistem dari hasil analisa dan perancangan yang telah dilakukan pada bab sebelumnya. Implementasi sistem merupakan tahap meletakan sistem sehingga siap untuk di operasikan.

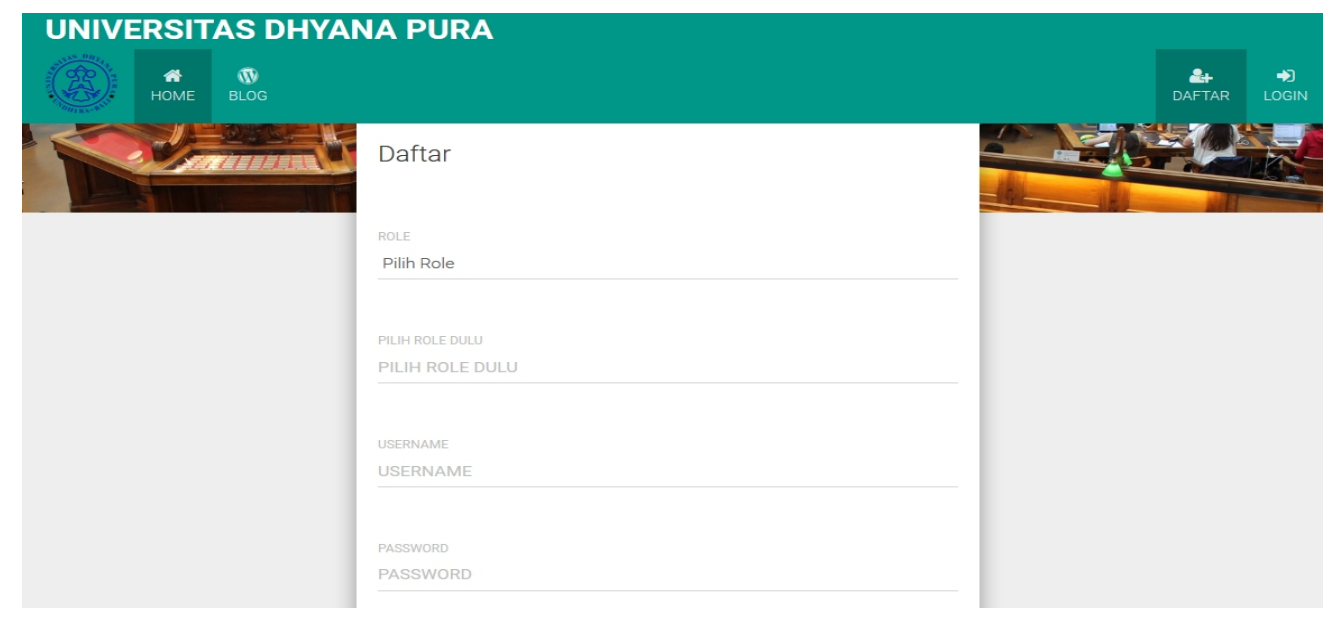

Gambar 5. Form Pendaftaran

Form ini berfungsi untuk masuk kedalam sistem informasi elearning, sebelum memasuki form login, pengguna harus mendaftar terlebih dahulu dan mengisi data diri seperti memilih role, masukan username, masukan password, dan konfirmasi password. 


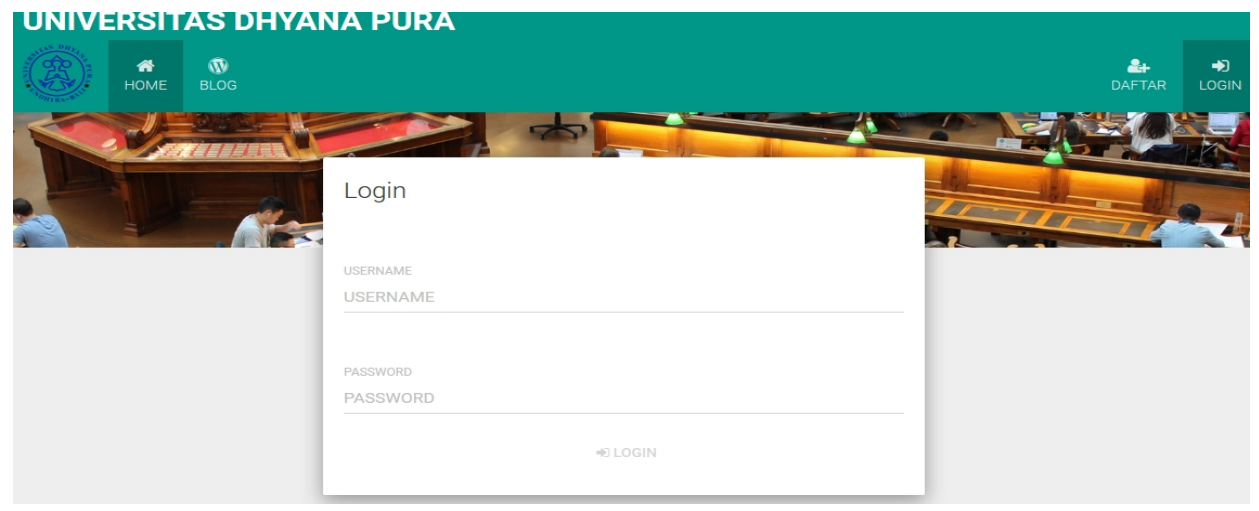

Gambar6.Tampilan Login E-learning

Setelah melakukan pendaftaran dan login dengan memasukan nama akun dan memiliki akun pada sistem informasi $e$ - username. learning, maka user dapat melakukan proses

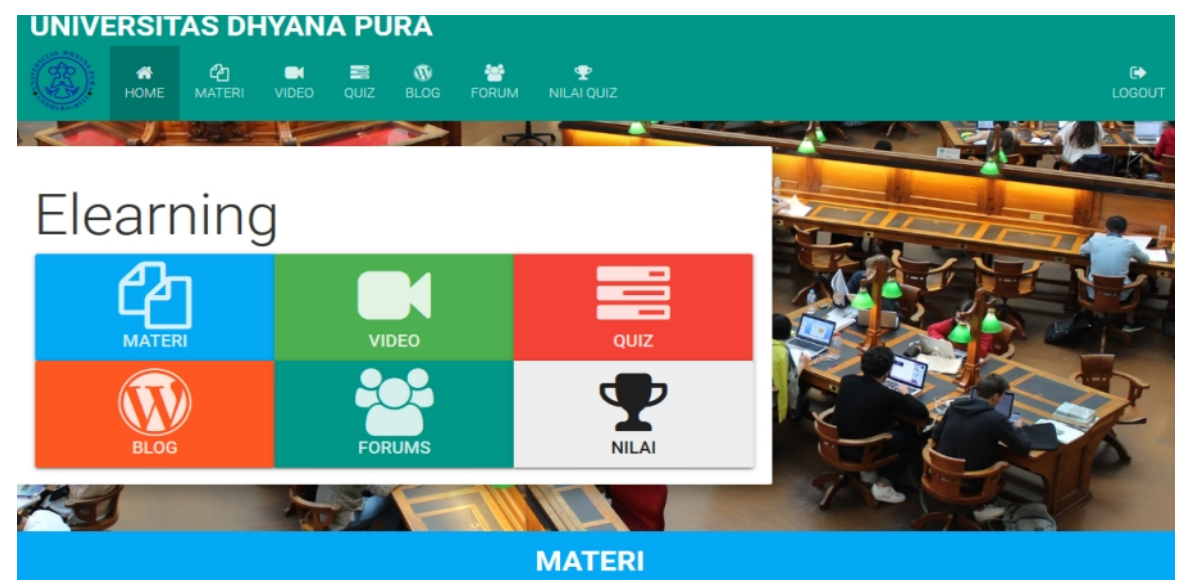

Gambar7.TampilanMenu UtamaE-learning

Setelah berhasil login dan masuk kedalam sistem maka akan muncul tampilan menu utama yang terdapat beberapa menu fasilitas yaitu materi, video, quiz, blog, forum dan nilai quiz.

\section{Simpulan}

Dari hasil penelitian yang dilakukan, maka penyusun menarik beberap akesimpulan bahwa

Penelitian ini telah berhasil merancang dan mengimplementasikan sistem informasi $e$ - learning berbasis web dengan metode random matrix untuk memfasilitasi kegiatan perkuliahan.

Dengan adanya sistem informasi ini diharapkan dapat memudahkan dan mempercepat proses pemberian informasi maupun materi pada proses perkuliahan di Universitas Dhyana Pura. Sistem informasi website ini memberikan informasi mengenai forum, quiz dan materi baik dalam bentuk text maupun video. 


\section{DAFTAR PUSTAKA}

[1] Clark, Ruth., Richard E.Mayer. 2008. ELearning - second edition. New York : Pfeiffer.

[2] Michael Chon. 2013. FASB Limits Fair Value Requirements for Private Companies and Nonprofits. Diakses pada tanggal 30 April 2016. Di Wide World

Web:

http://www.accountingtoday.com/news/ FASB-Limits-FairValue RequirementsPrivate-Companies-Nonprofits-656381.html

[3] Simarmata, Janner. 2006. Pengenalan Teknologi Komputer dan Informasi. Yogyakarta : Andi Offset. 